\title{
Inducible expression of heterologous genes targeted to a chromosomal platform in the cyanobacterium Synechococcus sp. PCC 7942
}

\author{
Dirk Geerts, Arnaud Bovy, + Geert de Vrieze, Mies Borrias \\ and Peter Weisbeek
}

Author for correspondence: Dirk Geerts. Tel: +31 30 532245. Fax: +31 30513655.
e-mail: wbtmcbw@cc.ruu.nl

Department of Molecular Cell Biology, University of Utrecht, Padualaan 8, 3584 CH Utrecht, The

Netherlands

\begin{abstract}
High-level, inducible expression of heterologous genes in the cyanobacterium Synechococcus sp. strain PCC 7942 was obtained using the Escherichia coli trc promoter and lacl repressor. The petE gene of Anabaena sp. strain PCC 7937 encoding plastocyanin precursor protein and the $E$. coli uidA gene encoding $\beta$ glucuronidase were initially placed under the control of the trc promoter and lacl repressor by cloning into the $E$. coli pTrc99C expression vector and were introduced into the chromosomal platform for integration in metF (PIM) of the Synechococcus R2-PIM9 recipient strain. These pTrc99C-derived constructs often gave rise to transformants that did not contain a complete insert gene, probably because of gene conversion events. Selection of the desired Synechococcus R2-PIM9 transformants was vastly improved using the new pTrclS vector that contains the aadA gene encoding streptomycin resistance as an extra antibiotic resistance marker. The influence of IPTG concentration and induction time on gene expression with the $E$. coli trcllacl system in Synechococcus was determined using $\beta$-glucuronidase as a reporter. The Anabaena PCC 7937 petE gene in Synechococcus was expressed to a high level upon induction with IPTG as shown by RNA and immunoblot analysis. The general usability of pTrclS as a cloning vector for inducible heterologous gene expression in Synechococcus was confirmed by the introduction of several more genes.
\end{abstract}

Keywords: Synechococcus sp. PCC 7942, cyanobacterium, heterologous gene expression, PIM, trc promoter/lacI repressor gene

\section{INTRODUCTION}

The cyanobacteria represent an ancient and diverse group of prokaryotes possessing a number of unique characteristics (Stanier \& Cohen-Bazire, 1977). Evolutionarily linked to chloroplasts (Gray, 1989), they are the simplest organisms capable of performing oxygenic photosynthesis, with a thylakoid apparatus remarkably similar to that of higher plant chloroplasts.

Cyanobacteria provide a simple but powerful experimental system for the analysis of the complex photo-

\footnotetext{
†Present address: DLO-Centre for Plant Breeding and Reproduction Research (CPRO-DLO), PO BOx 16, 6700 AA Wageningen, The Netherlands. Abbreviations: GUS, $\beta$-glucuronidase (EC 3.2.1.31); MCS, multiple cloning site; MU, 4-methylumbelliferone; MUG, 4-methylumbelliferone- $\beta$ D-glucuronide; PC, plastocyanin; PCC, Pasteur Culture Collection; PIM, platform for integration in the metF locus; RBS, ribosome-binding site.
}

synthesis process because of the possibility of combining biophysical and biochemical procedures with genetic manipulation techniques (Bryant, 1992; Vermaas, 1993). Several unicellular cyanobacterial species have a natural capability to take up heterologous DNA (Porter, 1986). Other cyanobacterial strains can be transformed using conjugation with Escherichia coli (Wolk et al., 1984) or electroporation (Thiel \& Poo, 1989), but until recently (Cai \& Wolk, 1990; Kuritz et al., 1993) techniques for gene transfer could only be exploited fully in the naturally transformable strains. These strains all belong to the genera Synecbococcus or Synechocystis (Rippka et al., 1979).

To study protein transport in cyanobacteria, in the work described here we introduced the genes encoding several precursor proteins from different cellular compartments into a cyanobacterial host. The unicellular strain Synechococcus sp. strain PCC 7942 was chosen as the host, because it is both physiologically and genetically well- 
characterized and highly transformable (Porter, 1986), either with vectors capable of autonomous replication (reviewed by Houmard \& Tandeau de Marsac, 1988) or by integration of heterologous DNA into the chromosome through homologous recombination. Using the latter approach, the major type of transformant normally results from 'gene replacement', an event in which a sequence in the recipient chromosome is replaced by a sequence from the donor DNA molecule (van der Plas et al., 1990; Williams \& Szalay, 1983).

The PIM (platform for integration in the met $F$ locus) system of Synechococcus PCC 7942 has been described previously (van der Plas et al., 1990). In the Synechococcus R2-PIM9 recipient strain used in this study, the chromosomal met $F$ locus is interrupted by an integration platform, consisting of a promoterless $E$. coli bla gene (encoding $\mathrm{Ap}^{\mathrm{R}}$ ) and the $\mathrm{pMB1}$ ori $V$, both from $\mathrm{pBR} 322$, separated by the neo gene (encoding $\mathrm{Km}^{\mathrm{R}}$ ). The platform enables integration of many pBR322-derived donor plasmids by homologous recombination at the bla and pMB1 ori $V$ sequences that are present in both the donor plasmid and the integration platform, independent of the insert DNA on the plasmid. The metF locus, normally involved in methionine biosynthesis, is a neutral site: it can be inactivated (e.g. by integration of heterologous DNA) without affecting the viability of the cells when the strain is grown on medium supplemented with methionine (van der Plas et al., 1990). By using a chromosomal expression system rather than a plasmid-bound one, copynumber effects (Scanlan et al., 1990; Elhai, 1993) were prevented, allowing careful comparisons of the different transgenic Synechococcus strains.

A system for inducible gene expression avoids possible harmful effects on the cyanobacterial host cell by constitutive expression of a heterologous gene, and also prevents selection for gene inactivation by host insertion sequences (Cai \& Wolk, 1990). We describe here the use of the E. coli trc promoter to obtain inducible, high-level expression of heterologous genes in Synechococcus PCC 7942 using control by the E. coli Lac repressor. This system was chosen because: (i) in E. coli the trc promoter is one of the strongest and best studied promoters (Brosius, 1987) and is tightly regulated by the Lac repressor (Amann et al., 1988); (ii) the trc promoter-lacI repressor combination has been successfully used in a wide range of both Gram-negative (Labes et al., 1990) and Gram-positive bacteria (Yansura \& Henner, 1984); (iii) E. coli consensus promoters like trc are efficient in cyanobacteria (Ferino \& Chauvat, 1989; Elhai, 1993); and (iv) the $\operatorname{trc}$ promoter can be induced by the addition of IPTG, which ought not to influence the metabolism of the cells.

Other inducible expression systems that have been described for use in cyanobacteria include the heat-shockinduced bacteriophage $\lambda \mathrm{P}_{\mathrm{L}} \mathrm{P}_{\mathrm{R}}$ promoter-cI857 $7^{\text {ts }}$ repressor system in Synechococcus PCC 7942 and PCC 6301 (Friedberg \& Seijffers, 1986; Mermet-Bouvier \& Chauvat, 1994), and the light-responsive Synechocystis PCC 6803 LR1 promoter in Synechococcus PCC 7942 and PCC 6301 (Marraccini et al., 1993). However, heat shock leads to drastic changes in protein synthesis and content (Borbély et al., 1985), and in the composition of intracellular membranes (Wada \& Murata, 1990), and readily affects photosynthetic activity by inactivation of photosystem II (Berry \& Bjorkman, 1980). Light also has many effects on gene expression and physiology in cyanobacteria (Tandeau de Marsac \& Houmard, 1993). Since we study cellular processes such as protein transport and photosynthesis, we wanted to avoid alteration of endogenous gene expression caused by the use of normal cellular activators such as light and temperature. The previously described systems therefore did not meet the criteria stated above.

\section{METHODS}

Organisms and culture conditions. The organisms used in this study are described in Table 1. E. coli strains were grown as described by Sambrook et al. (1989), and cyanobacterial strains were grown as described by Geerts et al. (1994). Synechococcus R2PIM9 transformation and transformant selection were performed according to the method of van der Plas et al. (1990). Recombinant Synechococcus R2-PIM9 strains containing construct pX are called Synechococcus R2-X.

Materials. Enzymes and oligonucleotides used for DNA cloning and sequencing procedures were purchased from Pharmacia. Radiolabelled nucleotides and Hybond-N membranes were from Amersham. Nitrocellulose filters and TLC plates were from Schleicher \& Schuell. Chemicals needed to prepare BG11 medium were from Merck. Plant agar was from Duchefa. BSA, Tween 20 and Triton X-100 were from Sigma. Equipment and chemicals for SDS-PAGE experiments were from Bio-Rad. Immobilon PVDF membrane was from Millipore. The Western Blot AP system was from Promega. 4-Methylumbelliferone (MU) fluorescence was measured with the Hoefer TKO 100. All other chemicals were from Boehringer.

DNA cloning, sequencing procedures and plasmid construction. The plasmids used in this study are listed in Table 1. Oligo site-directed mutagenesis was performed using E. coli HB2154 according to the method of Carter et al. (1985). DNA sequence analysis was performed using the T7 DNA sequencing kit (Pharmacia) according to the manufacturer's recommendations. Other DNA manipulations were as described previously (van der Plas et al., 1989; Geerts et al., 1994). All plasmid constructs were checked by DNA restriction and sequence analysis.

\section{Construction of plasmids}

pTrclS. p'TrcIS (6250 bp, see Fig. 4a) is similar to p'Trc99C but contains $\mathrm{Sm}^{\mathrm{R}}$ as an additional marker. It was constructed from pTrc97C, which contains a Bg/II site in place of the lac ${ }^{q}$ gene in pTrc99C. pTrcIS was assembled by ligation of a 2059 bp EcoRI fragment accommodating the aad $A$ gene (encoding $\mathrm{Sm}^{\mathrm{R}}$ ) from pUC7S together with a 1247 bp EcoRI fragment containing the lac $I^{\mathrm{q}}$ gene from $\mathrm{pPAFI}^{\mathrm{q}} 20$ into the $B g / \mathrm{II}$ site of $\mathrm{pTrc} 97 \mathrm{C}$ (2944 bp) after blunting of all three fragments with Klenow DNA polymerase. Transformants were selected for an $A p^{R} S^{R}$ phenotype by plating, and subsequently for the presence of the lacI gene by colony blot hybridization (Sambrook et al., 1989) using a specific DNA probe (see below). The orientation of the $\operatorname{aad} A$ and $\operatorname{lac}^{\mathrm{q}}$ genes is antiparallel to that of the bla gene. The sequence of pTrcIS is: bp 1-2938, p'Trc97C (bp 1-2938); bp 2939-2950, AATTCAGCTTGC (filled-in EcoRI site; EcoRIHindIII linker); bp 2951-4172, lacI ${ }^{\mathrm{a}}$ gene (p'Trc99C, bp 4170-2939); bp 4173-4189, GCAAGCT'TGAAT'TAATT (EcoRI-HindIII linker; filled-in EcoRI site; filled-in EcoRI site); 
Table 1. Bacterial strains and plasmids

\begin{tabular}{|c|c|c|}
\hline Strain/plasmid & Relevant characteristics & Source/reference \\
\hline \multicolumn{3}{|l|}{ Strain } \\
\hline E. coli $\mathrm{PC} 2495$ & $h s d S \operatorname{rec} A$ (JM101 derivative) & van der Plas et al. (1988) \\
\hline E. coli HB2154 & mutL & Carter et al. (1985) \\
\hline $\begin{array}{l}\text { Anabaena sp. } \\
\text { PCC } 7937\end{array}$ & & PCC \\
\hline $\begin{array}{l}\text { Synechococcus } \\
\text { PCC 7942-R2-PIM9 }\end{array}$ & $\begin{array}{l}\text { Recipient strain containing PIM platform } \\
\mathrm{Ap}^{\mathrm{s}} \mathrm{Km}^{\mathrm{R}} \mathrm{Sm}^{\mathrm{s}} \mathrm{Met}^{-}\end{array}$ & van der Plas et al. (1990) \\
\hline \multicolumn{3}{|l|}{ Plasmid } \\
\hline pACYC184 & cat gene, $\mathrm{Cm}^{\mathrm{R}}, 4 \cdot 2 \mathrm{~kb}$ & Rose (1988) \\
\hline pEMBL18 & $\mathrm{Ap}^{\mathrm{R}}, 4 \cdot 0 \mathrm{~kb}$ & Dente \& Cortese (1987) \\
\hline pEMBL19 & $A p^{R}, 4.0 \mathrm{~kb}$ & Dente \& Cortese (1987) \\
\hline $\mathrm{pPAFI}^{\mathrm{q}} 20$ & lacI $I^{q}$ gene, $\mathrm{Ap}^{\mathrm{R}}, 5 \cdot 2 \mathrm{~kb}$ & Pilon et al. (1990) \\
\hline pPCV6 & Anabaena PCC 7937 petE gene, Ap ${ }^{\mathrm{R}}, 6.4 \mathrm{~kb}$ & van der Plas et al. (1989) \\
\hline pRA81 & Synechococcus PCC 7942 pet $F$ gene, $\mathrm{Ap}^{\mathrm{R}}, 5 \cdot 1 \mathrm{~kb}$ & van der Plas et al. (1990) \\
\hline pRAJ275 & E. coli uid $A$ gene, $\mathrm{Ap}^{\mathrm{R}}, 4.6 \mathrm{~kb}$ & Sleat et al. (1987) \\
\hline pTrc97C & pMB1 oriV, Ptrc, $\mathrm{Ap}^{\mathrm{R}}, 2.9 \mathrm{~kb}$ & Amann et al. (1988) \\
\hline $\mathrm{p} \operatorname{Trc} 99 \mathrm{C}$ & pMB1 ori $V, P \operatorname{trc}$, lac $I^{\mathrm{q}}$ gene, $\mathrm{Ap}^{\mathrm{R}}, 4 \cdot 2 \mathrm{~kb}$ & Amann et al. (1988) \\
\hline pUC7S & aad $A$ gene, $A p^{\mathrm{R}}, \mathrm{Sm}^{\mathrm{R}}, 3.9 \mathrm{~kb}$ & van der Plas et al. (1990) \\
\hline p'TrcIS & pMB1 oriV, Ptrc, lac $I^{\mathrm{q}}, \mathrm{Ap}^{\mathrm{R}} \mathrm{Sm}^{\mathrm{R}}, 6.3 \mathrm{~kb}$ & This study \\
\hline pMG1 & Intermediate in pet $E$ gene construction, $A p^{R}, 4.0 \mathrm{~kb}$ & This study \\
\hline pMG2 & Intermediate in pet $E$ gene construction, $A p^{R}, 4 \cdot 8 \mathrm{~kb}$ & This study \\
\hline pMG59 & Intermediate in pet $E$ gene reconstruction, $\mathrm{Ap}^{\mathrm{R}}, 4.6 \mathrm{~kb}$ & This study \\
\hline pMG77A & Anabaena PCC 7937 petE gene in pTrc99C, Ap ${ }^{\mathrm{R}}, 4.8 \mathrm{~kb}$ & This study \\
\hline pMG95A & pMG77A with interrupted $l a c I^{\mathrm{q}}$ gene, $\mathrm{Ap}^{\mathrm{R}} \mathrm{Cm}^{\mathrm{R}}, 6.1 \mathrm{~kb}$ & This study \\
\hline pMG139A & E. coli uid $A$ gene in $\mathrm{p} T \mathrm{rc} 99 \mathrm{C}, \mathrm{Ap}^{\mathrm{R}}, 6.0 \mathrm{~kb}$ & This study \\
\hline pMG140A & pMG139A with interrupted lac $I^{\mathrm{q}}$ gene, $\mathrm{Ap}^{\mathrm{R}} \mathrm{Cm}^{\mathrm{R}}, 7 \cdot 4 \mathrm{~kb}$ & This study \\
\hline PMG145A & petE-amyL gene fusion in $\mathrm{p} T \mathrm{Trc} 99 \mathrm{C}, \mathrm{Ap}^{\mathrm{R}}, 6.0 \mathrm{~kb}$ & This study \\
\hline pMG77B & Anabaena PCC 7937 petE gene in pTrcIS, $\mathrm{Ap}^{\mathrm{R}} \mathrm{Sm}^{\mathrm{R}}, 6.9 \mathrm{~kb}$ & This study \\
\hline pMG95B & pMG77B with interrupted lac $I^{\mathrm{q}}$ gene, $\mathrm{Ap}^{\mathrm{R}} \mathrm{Cm}^{\mathrm{R}} \mathrm{Sm}^{\mathrm{R}}, 8 \cdot 2 \mathrm{~kb}$ & This study \\
\hline pMG139B & E. coli uid $A$ gene in $\mathrm{p} T r c I S, \mathrm{Ap}^{\mathrm{R}} \mathrm{Sm}^{\mathrm{R}}, 8.1 \mathrm{~kb}$ & This study \\
\hline pMG140B & pMG139B with interrupted lac $I^{\mathrm{q}}$ gene, $A \mathrm{p}^{\mathrm{R}} \mathrm{Cm}^{\mathrm{R}} \mathrm{Sm}^{\mathrm{R}}, 9 \cdot 4 \mathrm{~kb}$ & This study \\
\hline pMG145B & pet E-amyL gene fusion in pTrcIS, $A p^{\mathrm{R}} \mathrm{Sm}^{\mathrm{R}}, 8.0 \mathrm{~kb}$ & This study \\
\hline
\end{tabular}

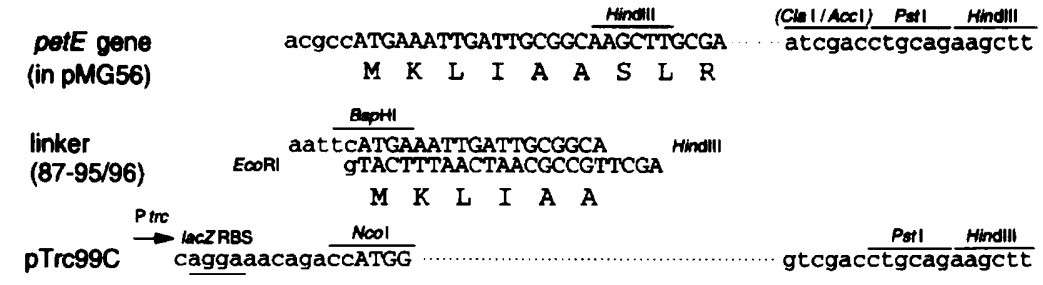

Fig. 1. Mutagenesis and reconstruction of the Anabaena PCC 7937 petE gene. Creation of a BspHI site spanning the ATG start codon of the Anabaena petE gene by use of adaptor 87-95/96. For details see Methods. Capital letters indicate the coding sequence of the petE gene. Overlined sequences indicate restriction sites used. Position and direction of the trc promoter in pTrc99C are indicated by an arrow. The lacZ RBS is underlined.

bp 4190-6240, aad $A$ gene [Prentki et al. (1991), bp 2067-16]; bp 6241-6250, AATTGATCTG (filled-in EcoRI site; filled-in Bg/II site). Because of sites present in the $\operatorname{lac}^{\mathrm{q}}$ and aad $A$ genes, the PstI, SpbI and HindIII sites in the multiple cloning site (MCS) are not unique. Unique sites in the MCS are NcoI, EcoRI, SstI, $K p n I, S m a I, B a m H I, X b a I$ and SalI.

pMG77/pMG95. A 760 bp Sau3AI-PstI fragment containing the entire Anabaena PCC 7937 petE gene from pPCV6 was ligated into pEMBL19 cut with Bam HI and Pst I, resulting in pMG59. The Sau3AI site is $104 \mathrm{bp}$ upstream of the petE gene, and the PstI site downstream from the petE gene is from the MCS of
pPCV6. To allow insertion of the petE gene into the NcoI site of pTrc99C or p TrcIS so that a translational fusion was established, a $B s p H I$ site spanning the ATG start codon of petE gene was created. $B s p \mathrm{HI}$ is compatible with $\mathrm{N} c o \mathrm{I}$ and the creation of this site does not result in changes in the nucleotide sequence of the pet $E$ gene coding region. The $B s p \mathrm{HI}$ site was made using adaptor 87-95/96 consisting of 22 bp of the pet $E$ gene (from -4 to the HindIII site at +18 ), flanked by EcoRI and HindIII sites and with a $B s p \mathrm{HI}$ site spanning the ATG codon (Fig. 1). The adaptor was ligated into pEMBL19 cut with EcoRI and HindIII, resulting in pMG1. The pet $E$ gene was reconstructed in $\mathrm{PMG1}$ 
by ligation of a 635 bp HindIII fragment from pMG59 into pMG1 cut with HindIII, resulting in pMG2. The petE gene was cloned into p'Trc99C or p'TrcIS cut with $N$ coI and PstI by ligation of the $650 \mathrm{bp} B s p \mathrm{HI}-P_{s t \mathrm{I}}$ fragment from pMG2, resulting in pMG77A or pMG77B, respectively. For interruption of the lacI gene, a $1330 \mathrm{bp} X m n \mathrm{I}-B c / \mathrm{I}$ fragment containing the cat gene (encoding $\mathrm{Cm}^{\mathrm{R}}$ ) from pACYC184 was blunted with Klenow DNA polymerase and ligated into pMG77A or pMG77B cut with PvuII, resulting in pMG95A or pMG95B, respectively. The orientation of the cat gene in pMG95A and pMB95B has not been determined.

pMG139/pMG140. The E. coli uid $A$ gene in pRA J275 has an NcoI site spanning the ATG start codon. To make a translational fusion of the uid $A$ gene, a $1855 \mathrm{bp} \mathrm{NcoI-EcoRI} \mathrm{fragment} \mathrm{from}$ pRA J275, containing the $E$. coli uid $A$ gene, was ligated into pTrc99C or pTrcIS cut with NcoI and EcoRI, resulting in pMG139A or pMG139B, respectively. The lacI gene in pMG139A and pMG139B was interrupted as described above, resulting in pMG140A and pMG140B, respectively. The orientation of the cat gene in PMG139B and pMG140B has not been determined.

pMG145. pMG86 is a construct containing the Anabaena PCC 7937 pet $E$ gene sequence encoding the PC signal peptide fused to the Bacillus licheniformis amyL gene sequence encoding $\alpha$ amylase mature protein (D. Geerts and others, unpublished results). The petE-amyL gene fusion was cloned into pTrc99C or pTrcIS cut with $N c o \mathrm{I}$ and $S_{s t \mathrm{I}}$ by ligation of a $1785 \mathrm{bp}$ $N c o I-S_{s t 1}$ fragment from $\mathrm{pMG} 86$, resulting in $\mathrm{pMG} 145 \mathrm{~A}$ or pMG145B, respectively.

Synechococcus colony blot hybridization. Synechococcus transformants were screened for the presence of a heterologous gene by colony blot hybridization using a specific DNA probe (see below). Cells were streaked on nitrocellulose filters on top of BG11 plates as well as directly on BG11 master plates and grown for 4-7 d. Lysis of the cell streaks using SDS and $\mathrm{NaOH}$ was as described by Sambrook et al. (1989), except that the incubation with $2 \times \mathrm{SSC}$ was omitted. After baking, the filters were shaken at $37^{\circ} \mathrm{C}$ in $2 \times$ SSPE, $0.1 \%(w / v)$ SDS and $50 \mu \mathrm{g} \mathrm{ml}^{-1}$ proteinase $\mathrm{K}$ for $1 \mathrm{~h}$, and in $2 \times \operatorname{SSPE}, 0 \cdot 1 \%(\mathrm{w} / \mathrm{v})$ $\mathrm{SDS}$ for $30 \mathrm{~min}$ to remove cell debris. The filters were prehybridized for $1 \mathrm{~h}$ at $42{ }^{\circ} \mathrm{C}$ in $50 \%(\mathrm{v} / \mathrm{v}$ ) formamide, $5 \times \mathrm{SSPE}$, $5 \times$ Denhardt's solution, $0.1 \%(\mathrm{w} / \mathrm{v})$ SDS and $0.1 \mathrm{mg}$ denatured salmon-sperm DNA $\mathrm{ml}^{-1}$ (Sambrook et al., 1989). Hybridization was initiated by the addition of denatured probe DNA to the pre-hybridization medium, followed by incubation at $42{ }^{\circ} \mathrm{C}$ for $16 \mathrm{~h}$. Blots were washed twice for $5 \mathrm{~min}$ at room temperature and twice for $15 \mathrm{~min}$ at $42{ }^{\circ} \mathrm{C}$ in $1 \times \mathrm{SSPE}, 0.1 \%$ $(\mathrm{w} / \mathrm{v})$ SDS. Autoradiography was for $4-16 \mathrm{~h}$ at $-70^{\circ} \mathrm{C}$. The Anabaena PCC 7937 petE probe used was a 400 bp HindIII-NheI fragment containing most of the pet $E$ gene coding region from pPCV6, and the E. coli uid $A$ probe was a $1180 \mathrm{bp} B c l \mathrm{I}-S_{s} p \mathrm{I}$ fragment internal to the uid $A$ gene from pRAJ275. Radiolabelling was performed as described by Feinberg \& Vogelstein (1983).

RNA isolation and RNA:DNA hybridization. RNA isolation and RNA: DNA blot hybridization were performed as described by Bovy et al. (1992). RNA dot blots were prepared on Hybond$\mathrm{N}$ membranes (Amersham) according to the manufacturer's instructions. The probe used for petE mRNA is described above, and a $360 \mathrm{bp} S s t \mathrm{I}-E c o \mathrm{RI}$ fragment containing most of the Synechococcus PCC 7942 pet $F$ gene coding region from $p R A 81$ was used as a probe for petF mRNA. A $620 \mathrm{bp} \mathrm{BstEII-NsiI}$ fragment internal to the lacI gene from pTrc99C was the probe for lacI mRNA. Radiolabelling was performed as described above.
Protein isolation and immunoblot analysis. Cultures of E. coli cells harbouring pMG constructs were grown to mid-exponential phase by $1: 100$ dilution of an overnight culture into $100 \mathrm{ml}$ Luria-Bertani medium followed by growth at $37^{\circ} \mathrm{C}$ for 2-3 h. Cultures were divided into $50 \mathrm{ml}$ batches and grown for an additional $3 \mathrm{~h}$ in the presence or absence of $1 \mathrm{mM}$ IPTG. Cells were harvested at $4{ }^{\circ} \mathrm{C}$ by centrifugation $(10 \mathrm{~min}$ at $4000 \mathrm{~g}$ ), washed in $10 \mathrm{mM}$ Tris $/ \mathrm{HCl}$ ( $\mathrm{pH} \mathrm{8.0)}$ ), and resuspended in $1 \mathrm{ml}$ of the same buffer. Cultures of Anabaena and Synechococcus R2-PIM9 derivatives were grown to $15 \mu \mathrm{g}$ chlorophyll $a \mathrm{ml}^{-1}$ as described by Geerts et al. (1994). Induction and harvest were as described above, but induction was for the last $16 \mathrm{~h}$ of growth and harvesting was at room temperature. Protein concentration was determined as described by Geerts et al. (1994). Protein $(50 \mu \mathrm{g})$ was separated on $15 \%(\mathrm{w} / \mathrm{v})$ SDS-PAGE gels as described by Laemmli (1970). Preparation and screening of immunoblots and polyclonal antiserum 8806 against Anabaena PCC 7937 PC were as described by Geerts et al. (1994). Polyclonal antiserum against E. coli LacI protein was a gift from Dr Ponzy Lu (Department of Chemistry, University of Pennsylvania, PA, USA).

$\boldsymbol{\beta}$-Glucuronidase (GUS) assay. Cultures $(10 \mathrm{ml})$ of $E$. coli cells harbouring pMG139A or pMG140A, and Synechococcus R2MG139A or R2-MG140A were grown and harvested as described above, washed in $50 \mathrm{mM}$ sodium phosphate buffer ( $\mathrm{pH} 7 \cdot 0$ ), and resuspended in $0.25 \mathrm{ml}$ phosphate buffer containing $10 \mathrm{mM}$ EDTA and $10 \mathrm{mM} \beta$-mercaptoethanol. Cells were lysed by sonication. Sarkosyl and Triton X-100 were added to $0.1 \%(\mathrm{v} / \mathrm{v})$, the suspension was mixed, incubated for $10 \mathrm{~min}$ on ice, and cell debris was removed by centrifugation for $10 \mathrm{~min}$ at $6000 \mathrm{~g}$. GUS activity in the extracts was assayed using 4-methylumbelliferone- $\beta$-D-glucuronide (MUG) as a substrate according to the method of Vorst et al. (1990). The values obtained were converted into specific activity using a calibration curve with known amounts of $\mathrm{MU}$ product (relative fluorescence $10000 \mu \mathrm{mol}^{-1}$ ).

\section{RESULTS}

\section{Plasmid construction and expression in E. coli}

pTrc99C (Fig. 2a) is a $4.2 \mathrm{~kb}$ pBR322-derived plasmid that contains the E. coli trc promoter followed by the lac $Z$ ribosome-binding site (RBS) upstream from a unique NcoI site comprising the ATG start codon of the lac $Z$ gene. The NcoI site is followed by the pEMBL18 MCS and the $E$. coli $r r n B$ transcription terminator sequence. Insertion of a gene into this NcoI site so that the NcoI site spans its ATG start codon allows expression of the corresponding protein translated under the control of the lacZ RBS. Additionally, the plasmid contains the lacI gene encoding the Lac repressor for controlled expression of the insert gene. The lacI gene itself is constitutively expressed at a high level by its $\operatorname{lacI}^{\mathrm{q}}$ promoter 'up'mutation. In the absence of IPTG, the Lac repressor blocks the trc promoter. Addition of IPTG results in inactivation of the Lac repressor, derepression of the $\operatorname{trc}$ promoter, and subsequent high-level expression of the insert gene. The insert gene and the lacI gene are flanked by the E. coli bla gene (encoding $\mathrm{Ap}^{\mathbf{R}}$ ) and the $\mathrm{pMB} 1$ ori $V$ sequence, a prerequisite for legitimate recombination into the integration platform of the Synechococcus R2-PIM9 recipient strain (Fig. 2b). pTrc99C-derived expression plasmids in this study are called pMGx-A (Table 1). 
(a)

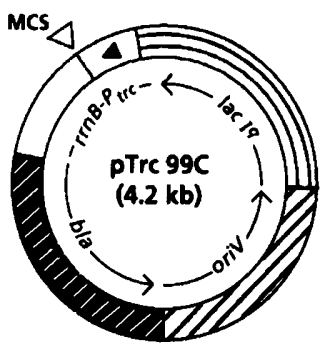

(b)

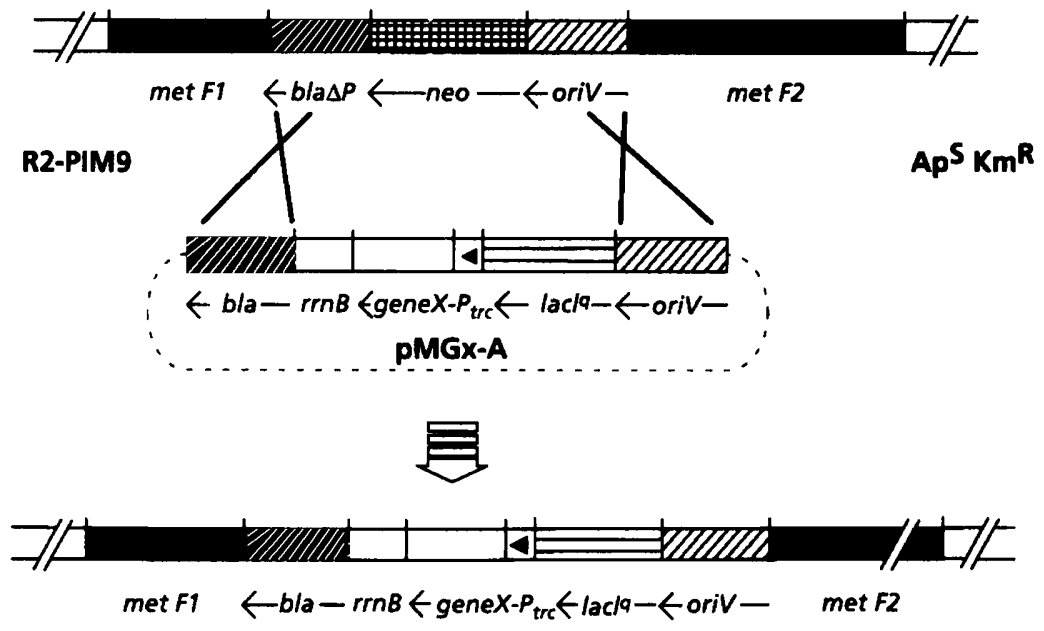

Fig. 2. Integration of a pMGX-A construct in the PIM of Synechococcus R2-PIM9. (a) The pTrc99C vector. Specific genes studied were placed under the control of the trc promoter by insertion in the $\mathrm{Ncol}$ site in the MCS of the vector. PTrc99C-derived constructs were called pMGx-A. The lacla gene product renders the trc promoter repressed in the absence of IPTG. The bla gene encodes $A p^{R}$. Arrows indicate the direction of transcription. (b) Integration of pMGX-A in the platform of Synechococcus R2-PIM9 $\left(A p^{5} \quad \mathrm{Km}^{\mathrm{R}}\right)$ via homologous recombination at the bla and $\mathrm{pMB1}$ oriv regions. The neo gene (encoding $\mathrm{Km}^{\mathrm{R}}$ ) in the platform is replaced by the expression cassette (trc promoter, insert gene, rrnB terminator, and lacl gene) present in pMGXA. The crosses depict the cross-over events. The absence of the bla promoter is indicated by $\triangle P$. pMGx-A is drawn as a linear structure for reasons of presentation. The dashed lines indicate that plasmid DNA used to transform Synechococcus was in fact circular. The desired recombinant has an $\mathrm{Ap}^{\mathrm{R}} \mathrm{Km}^{\mathrm{s}}$ phenotype.
The Anabaena PCC 7937 petE gene (van der Plas et al., 1989) encodes the precursor protein of plastocyanin (PC), a copper protein active in the thylakoid lumen as electron donor to photosystem I. The petE gene was cloned into the NcoI site of pTrc 99 C, creating a translational fusion, as depicted in Fig. 1. The resulting plasmid was called pMG77A. As a control, the lacI gene in PMG77A was interrupted by insertion of a cat gene (encoding $\mathrm{Cm}^{\mathrm{R}}$ ), resulting in pMG95A. Expression of the Anabaena petE gene in $E$. coli was determined by immunoblotting using a specific antiserum (Fig. 3). In cells containing pMG95A, expression of the Anabaena petE gene was efficient and independent of the presence of IPTG (lanes 1 and 2). Cells with pMG77A showed expression of the Anabaena pet $E$ gene only after IPTG induction (lanes 3 and 4). In E. coli cells containing the pTrc99C vector, no PC could be detected (lanes 5 and 6 ).

Likewise, the E. coli uid $A$ gene encoding GUS (Jefferson et al., 1986) was cloned into pTrc99C, creating a translational fusion. This resulted in plasmids pMG139A (with an intact lacI gene) and pMG140A (with an interrupted lacI gene). Expression of the uid $A$ gene in $E$. coli was tested by determination of GUS activity. In cells containing pMG139A, the level of GUS activity was 10-20 times higher in induced cells than in non-induced cells. GUS activity in cells containing pMG140A was of the same order as that in induced pMG139A cells, and was independent of the presence of IPTG.

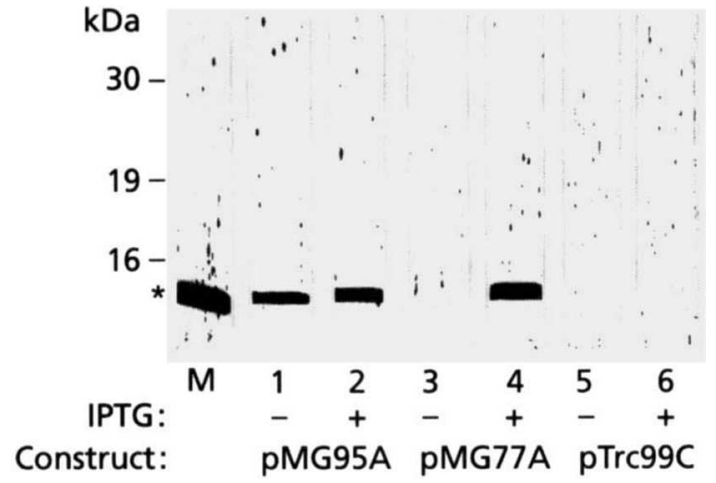

Fig. 3. Expression of the Anabaena petE gene in $E$. coli. Cultures of $E$. coli clones harbouring PMG77A, pMG95A or pTrc99C were grown, induced with IPTG and harvested as described in Methods. Immunoblots were screened with antiserum specific for Anabaena PC. The position of PC is marked with an asterisk. Lane $M$ represents the positive control, mature PC isolated from Anabaena.

\section{Transfer of expression constructs to Synechococcus R2-PIM9}

The pMGx-A expression plasmids and $\mathrm{p} \operatorname{Trc} 99 \mathrm{C}$ (as a control) were transferred to Synechococcus R2-PIM9. The recombination event leading to chromosomal integration in R2-PIM9 using a pMGx-A construct is represented in Fig. 2(b). Recombination results in restoration of a 


\section{Table 2. Transfer of pMGx-A constructs to Synechococcus R2-PIM9}

Transformation was performed as described in Methods. Phenotypes were determined by plate screening. Gene presence was determined by colony blot hybridization, and inducible gene expression was determined by protein blotting, as described in Methods. Transformation efficiency is expressed in transformants per ng DNA and $n$ indicates the number of experiments.

\begin{tabular}{|c|c|c|c|c|c|c|}
\hline \multirow[t]{3}{*}{ Vector } & \multirow[t]{3}{*}{ Selection } & \multirow{3}{*}{$\begin{array}{c}\text { Transformation } \\
\text { efficiency }\end{array}$} & \multirow[t]{3}{*}{$N^{*}$} & \multicolumn{3}{|c|}{$\mathrm{Ap}^{\mathrm{R}} \mathrm{Km}^{\mathrm{s}}$ transformants } \\
\hline & & & & \multirow[t]{2}{*}{ Number } & \multicolumn{2}{|c|}{ Insert gene } \\
\hline & & & & & Present & Expressed \\
\hline pMG77A & $A p^{R}$ & $118 \pm 62(n=3)$ & 148 & $6(4 \%)$ & $6(100 \%)$ & $0(0 \%)$ \\
\hline pMG95A & $\mathrm{Ap}^{\mathrm{R}}$ & $176 \pm 148(n=4)$ & 150 & $17(11 \%)$ & $16(94 \%)$ & $0(0 \%)$ \\
\hline pMG139A & $\mathrm{Ap}^{\mathrm{R}}$ & $35 \pm 12(n=3)$ & 171 & $43(25 \%)$ & $12(28 \%)$ & $3(25 \%)$ \\
\hline pMG140A & $A p^{R}$ & $91 \pm 51(n=3)$ & 176 & $42(24 \%)$ & $9(21 \%)$ & $2(22 \%)$ \\
\hline pMG145A & $\mathrm{Ap}^{\mathrm{R}}$ & $101 \pm 75(n=7)$ & 48 & $9(19 \%)$ & $4(44 \%)$ & $0(0 \%)$ \\
\hline pTrc99C & $A p^{R}$ & $208 \pm 106(n=5)$ & 129 & $13(10 \%)$ & NA & NA \\
\hline
\end{tabular}

NA, Not applicable.

$* N$, number of $\mathrm{Ap}^{\mathrm{R}}$ transformants used in further testing.

functional bla gene, conferring an $\mathrm{Ap}^{\mathrm{R}}$ phenotype upon the cell, and replacement of the neo gene of the platform by the insert gene present on the pMGx-A donor plasmid ('gene replacement'). Synechococcus transformants resulting from a gene replacement event are obtained by selection for an $\mathrm{Ap}^{\mathbf{R}}$ phenotype, and subsequent screening for loss of the $\mathrm{Km}^{\mathrm{k}}$ platform marker by plating and for the presence of the insert DNA by colony blot hybridization using a specific DNA probe.

Transformation of the R2-PIM9 strain with the pMGx-A constructs was very efficient (Table 2); 35-208 $\times 10^{3} \mathrm{Ap}^{\mathrm{R}}$ transformants were obtained per $\mu \mathrm{g}$ DNA, which was similar to data obtained by Williams \& Szalay (1983). Only 4-25\% (depending on the construct transferred) of the $A p^{\mathbf{R}}$ transformants had lost the $\mathrm{Km}^{\mathbf{R}}$ marker gene function contained on the platform. The majority of the transformants $\left(\mathrm{Ap}^{\mathrm{R}} \mathrm{Km}^{\mathrm{R}}\right)$ resulted from a single crossover event at the bla gene sequence and consequently contained not only the insert gene in the chromosome, but also other parts of the donor plasmid ("plasmid addition'). The transformants were highly unstable and quickly lost parts of the insert from the chromosome, as described previously (Williams \& Szalay, 1983).

Even transformants with the correct $A p^{R} \mathrm{Km}^{\mathrm{S}}$ phenotype did not necessarily have the proper genetic structure. Most $\mathrm{Ap}^{\mathrm{R}} \mathrm{Km}^{\mathrm{S}}$ transformants did not contain the insert gene as judged by colony blot hybridization. Screening, by immunoblotting, of $A p^{R} \mathrm{Km}^{\mathrm{s}}$ transformants that did react with the probe failed to show synthesis of the encoded protein. Colony blot hybridization of the $A p^{\mathbf{R}}$ $\mathrm{Km}^{\mathrm{S}}$ transformants with DNA probes specific for small regions of the donor DNA confirmed that the DNA transferred to the recipient platform in the transformants varied in length, and most transformants did not contain a complete insert gene. This indicated that in these transformants a cross-over had occurred in the bla gene, followed by a second, illegitimate recombination event proximal to the ori $V$ sequence ('gene conversion' or nonreciprocal recombination). The yield of correct transformants was very different for the various constructs tested (Table 1 and results not shown), implying influence of the insert DNA on the recombination process. For some constructs we were not able to obtain the desired clones, although several hundred $A \mathrm{p}^{\mathrm{R}}$ transformants were screened.

To improve the selection of the desired Synechococcus transformants, the pTrc99C vector was modified. Recombination in the bla gene results in a changed phenotype (from $A p^{\mathrm{S}}$ to $A \mathrm{p}^{\mathrm{R}}$ ), whereas recombination in the oriV region does not. Rather than alter the PIM, we decided to insert a second antibiotic resistance marker between the lacI gene and the oriV sequence in the donor plasmid. Screening of Synechococcus transformants for resistance to this marker (in combination with selection for $A p^{R}$ ) should lead to selection of transformants that had the complete expression cassette (trc promoter, insert gene, $r r n B$ terminator sequence, and lacI gene) transferred to the chromosome. Insertion of the aad $A$ gene encoding $\mathrm{Sm}^{\mathrm{R}}$ into a precursor of the pTrc99C vector resulted in the construction of plasmid pTrcIS (Fig. 4a). Genes of interest were cloned into p'TrcIS resulting in the pMGx-B expression constructs (Table 1). Fig. 4(b) is a schematic representation of the recombination events leading to chromosomal integration in R2-PIM9 using a pMGx-B construct as donor plasmid.

The efficiency of transformation of Synechococcus R2-PIM9 with pMG145B and pTrcIS (as a control) depended upon the selection applied (Table 3); 75-90 $10^{3} \mathrm{Ap}^{\mathrm{R}}$ transformants were obtained per $\mu \mathrm{g}$ DNA. When the first selection of the transformants was for an $\mathrm{Ap}^{\mathrm{R}}$ phenotype, only 2 or $9 \%$ of the $A p^{R}$ transformants had acquired the $\mathrm{Sm}^{\mathrm{R}}$ gene and lost the $\mathrm{Km}^{\mathrm{R}}$ platform marker function (compare with Table 2). In contrast, selection of transformants directly for an $A p^{R} S^{R}$ phenotype gave a 74- 
(a)

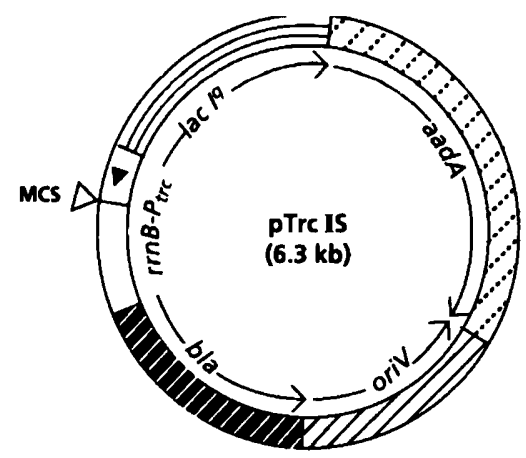

(b)

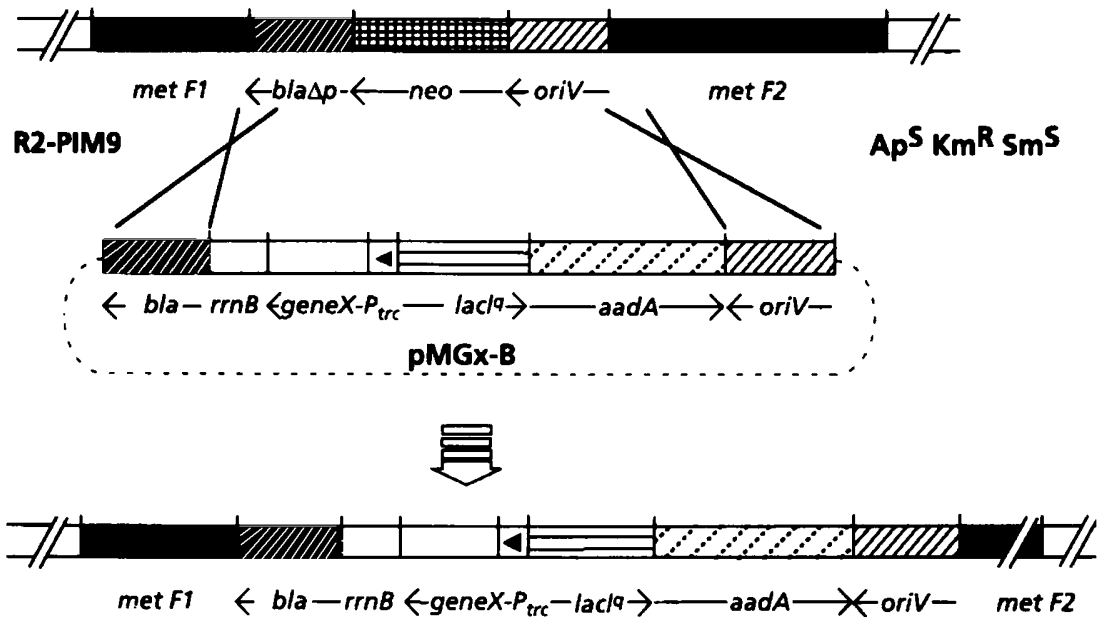

R2-MGX-B

$A p^{R} \mathrm{Km}^{\mathrm{S}} \mathrm{Sm}^{\mathrm{R}}$
Fig. 4. Integration of a $\mathrm{pMGX}-\mathrm{B}$ construct in the PIM of Synechococcus R2-PIM9. (a) In comparison to pTrc99C, pTrclS contains the $E$. coli $\operatorname{aadA}$ gene encoding $\mathrm{Sm}^{\mathrm{R}}$ as an additional marker gene. The aad $A$ gene and bla gene flank the expression cassette. pTrclS-derived constructs were called pMGxB. (b) Integration of pMGx-B in the platform of Synechococcus R2-PIM9 via homologous recombination. The desired recombinant has an $\mathrm{Ap}^{R} \mathrm{Km}^{5} \mathrm{Sm}^{R}$ phenotype. Other details are as in Fig. 2.

Table 3. Transfer of pMGx-B constructs to Synechococcus R2-PIM9

See Table 2 legend for details.

\begin{tabular}{|c|c|c|c|c|c|c|}
\hline \multirow[t]{3}{*}{ Vector } & \multirow[t]{3}{*}{ Selection } & \multirow{3}{*}{$\begin{array}{c}\text { Transformation } \\
\text { efficiency }\end{array}$} & \multirow[t]{3}{*}{$N^{*}$} & \multicolumn{3}{|c|}{$A p^{R} \mathrm{Sm}^{R} K m^{S}$ transformants } \\
\hline & & & & \multirow[t]{2}{*}{ Number } & \multicolumn{2}{|c|}{ Insert gene } \\
\hline & & & & & Present & Expressed \\
\hline \multirow[t]{3}{*}{ pMG145B } & $A p^{R}$ & $88 \pm 72(n=9)$ & 62 & $1(2 \%)$ & $0(0 \%)$ & $0(0 \%)$ \\
\hline & $A p^{R} S m^{R}$ & $0 \cdot 2 \pm 0 \cdot 2(n=8)$ & 66 & $52(79 \%)$ & $52(100 \%)$ & $52(100 \%)$ \\
\hline & $\mathrm{Sm}^{\mathrm{R}}$ & $2 \cdot 3 \pm 0.7(n=8)$ & 276 & $240(87 \%)$ & $+(100 \%)$ & $\dagger(100 \%)$ \\
\hline \multirow[t]{3}{*}{ p'TrcIS } & $A p^{R}$ & $74 \pm 79(n=5)$ & 22 & $2(9 \%)$ & NA & NA \\
\hline & $A p^{R} S m^{R}$ & $1 \cdot 0 \pm 1 \cdot 1(n=4)$ & 18 & $16(89 \%)$ & NA & NA \\
\hline & $\mathrm{Sm}^{\mathrm{R}}$ & $7 \cdot 9 \pm 3.5(n=4)$ & 99 & $97(98 \%)$ & $\mathrm{NA}$ & NA \\
\hline
\end{tabular}

NA, Not applicable.

$* N$, number of $\mathrm{Ap}^{\mathrm{R}}$ transformants used in further testing.

†Only 50 transformants were tested.

or 440 -fold lower yield in transformants per $\mu \mathrm{g}$ DNA, but 79 or $89 \%$ of these transformants had the desired $\mathrm{Ap}^{\mathrm{R}}$ $\mathrm{Sm}^{\mathrm{R}} \mathrm{Km}^{\mathrm{S}}$ phenotype, respectively. When transformants with this phenotype were analysed further, all contained the complete expression cassette, as confirmed by the regulated expression of the insert gene. When the first selection of the transformants was for $\mathrm{Sm}^{\mathrm{R}}$, approximately 10 -fold more transformants were obtained than when the 


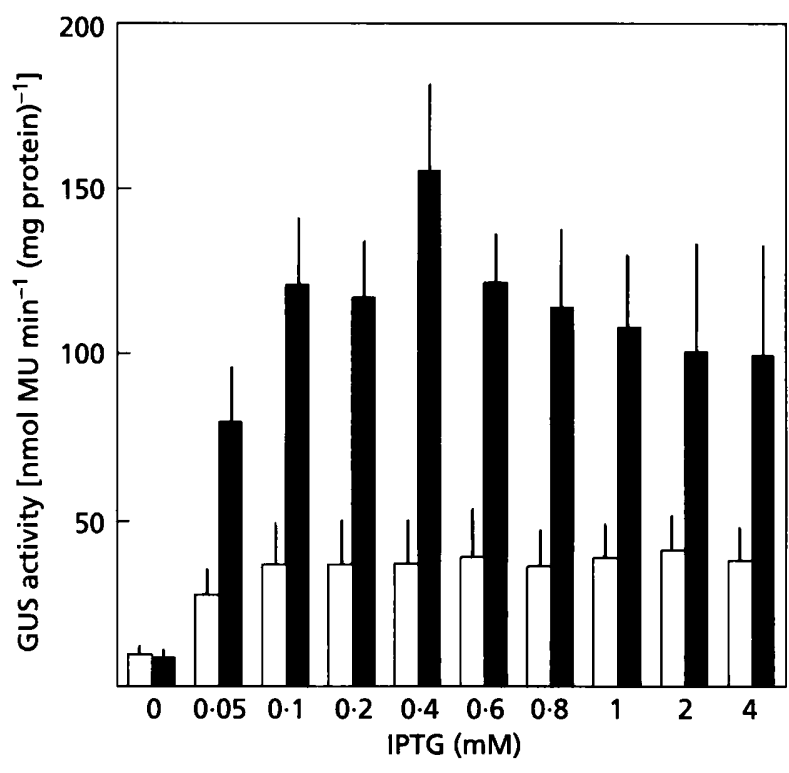

Fig. 5. GUS activity in Synechococcus as a function of IPTG concentration. Synechococcus R2-MG139A was grown as described and equal batches of culture were induced with varying concentrations of IPTG. Cells were harvested $4 \mathrm{~h}$ (open bars) or $24 \mathrm{~h}$ (filled bars) after the addition of IPTG, and GUS activity was determined. Vertical lines represent standard deviation, determined from five experiments.

first selection was for $A p^{R} S m^{R}$, whereas the percentage of transformants with an $\mathrm{Ap}^{\mathrm{R}} \mathrm{Sm}^{\mathrm{R}} \mathrm{Km}^{\mathrm{S}}$ phenotype was even higher. In some cases, e.g. with pMG145, the desired recombinant Synechococcus clone could only be isolated by transformation with a $\mathrm{pMGx}-\mathrm{B}$ construct.

\section{Analysis of expression conditions in Synechococcus using GUS as a reporter}

The strength of the E. coli trc promoter and the optimum conditions for inducible gene expression in Synechococcus were determined using the $E$. coli uid $A$ gene encoding GUS as a reporter. The strains studied were Synechococcus R2-MG139A and R2-MG140A. The conditions tested were IPTG concentration and induction time. Fig. 5 shows the results of induction experiments with R2MG139A in which the IPTG concentration was varied, and cells harvested 4 or $24 \mathrm{~h}$ after the addition of IPTG. GUS activity reached a maximum level at concentrations of $0.1 \mathrm{mM}$ IPTG and higher. After $4 \mathrm{~h}$ the increase in GUS activity was 4-fold compared to the level in noninduced cells, and after $24 \mathrm{~h}$ the increase was 16-fold. A time-course experiment (Fig. 6) showed that induced expression in R2-MG139A was maximum after $48 \mathrm{~h}$, and 36-fold higher than in non-induced cells. Induced expression in R2-MG139A cells reached the level of constitutive expression in R2-MG140A cells.

\section{Expression of the Anabaena petE gene in Synechococcus}

Synechococcus R2-MG77B, R2-MG95B, R2-TrcIS (as a negative control) and Anabaena (as a positive control)

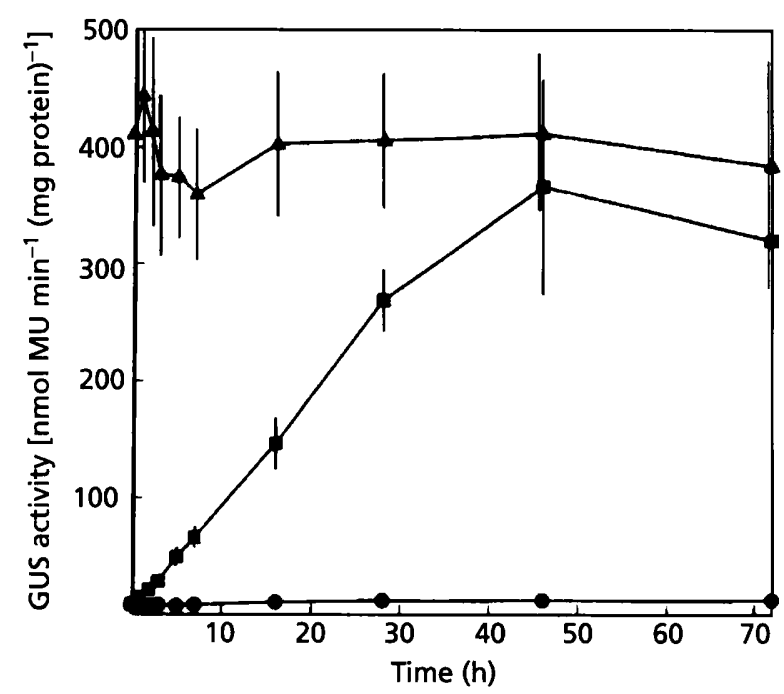

Fig. 6. GUS activity in Synechococcus as a function of induction time. Synechococcus R2-MG139A and R2-MG140A cultures were grown as described. Equal batches of R2-MG139A culture were induced with $1 \mathrm{mM}$ IPTG ( $(\mathbf{)})$ or not induced (O), and R2MG140A was not induced $(\boldsymbol{\Lambda})$. Cells were harvested at various times of induction and GUS activity was determined. Standard deviation is presented as in Fig. 5.

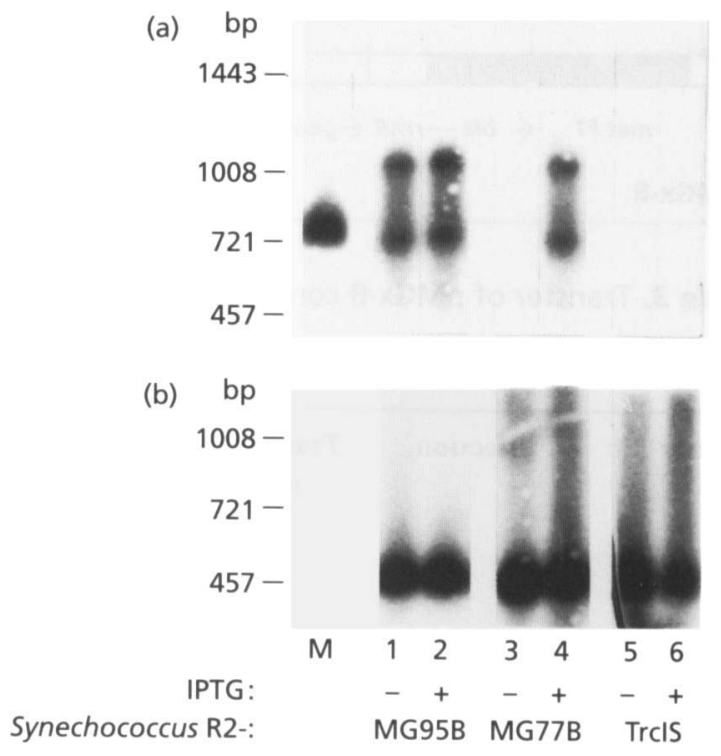

Fig. 7. Expression of the Anabaena petE gene in Synechococcus: mRNA. Cultures of Synechococcus R2-MG77B, R2-MG95B, and R2-TrclS and of Anabaena were grown as described in Methods and induced or not induced with IPTG. (a) RNA blot screened with a DNA probe specific for Anabaena petE mRNA. (b) Blot from (a) stripped and re-screened with a DNA probe specific for Synechococcus PCC 7942 petF mRNA.

were tested for expression of the Anabaena petE gene using RNA and immunoblot analysis. Fig. 7(a) shows an RNA blot probed with a DNA fragment carrying the Anabaena petE gene. In Synechococcus R2-MG95B cells, 
(a) $\mathrm{kDa}$

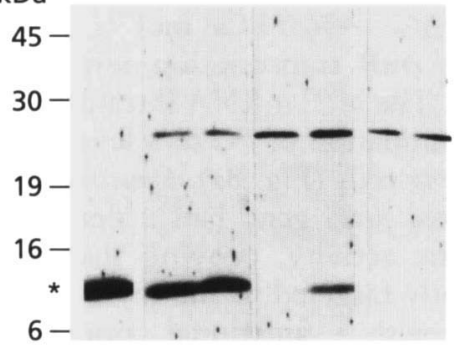

(b) $\mathrm{kDa}$

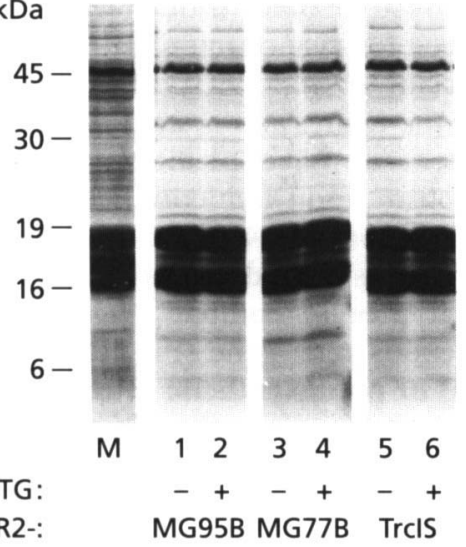

Fig. 8. Expression of the Anabaena petE gene in Synechococcus: protein. (a) Immunoblot of the cells in Fig. 7 screened with antiserum specific for Anabaena PC. Lane M represents the positive control (see Fig. 3). The position of PC is marked with an asterisk. (b) SDS-PAGE gel as in (a) stained with Coomassie Brilliant Blue.

pet $E$ mRNA was present as expected in both the absence and presence of IPTG (lanes 1 and 2). In Synechococcus R2MG77B cells, petE mRNA was detected only after induction with IPTG (lanes 3 and 4). Synechococcus R2TrcIS cells did not contain petE mRNA (lanes 5 and 6 ). The petE mRNA detected in Synechococcus cells had two different sizes, one of approximately 740 bases, and a larger one of approximately 1030 bases. In Anabaena cells (lane $M$ ), a single pet $E$ transcript of about 740 bases long was present (Bovy et al., 1992). To show that incubation of the cells with IPTG had no deleterious effect on the transcriptional capacity of the cells in general, the blot used in Fig. 7(a) was stripped and re-probed with a DNA fragment carrying the Synechococcus PCC 7942 petF gene encoding ferredoxin (van der Plas et al., 1990). The results (Fig. 7b) showed that all lanes contained similar amounts of pet $F$ mRNA. Densitometric scanning confirmed that the concentration of petF mRNA differed only up to $15 \%$, with no apparent relation to the absence or presence of IPTG (results not shown).

Protein levels also varied as expected in response to IPTG. In cells of strain R2-MG95B, expression of Anabaena PC was independent of the addition of IPTG (Fig. 8a, lanes 1 and 2). The protein detected was the same size as mature PC protein in Anabaena cells (lane M), (a)

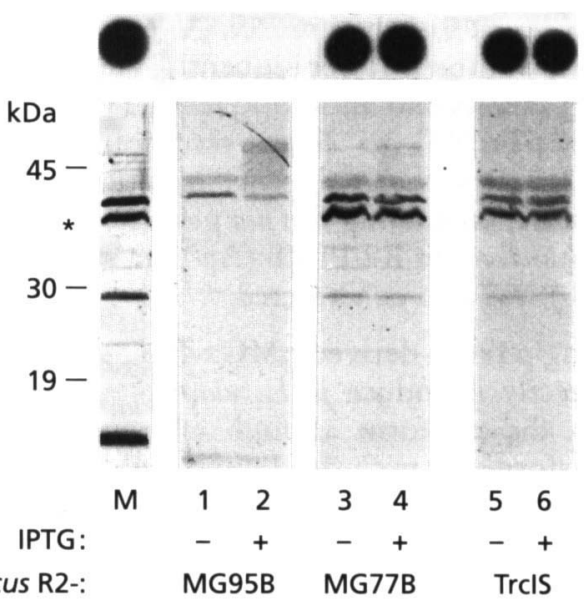

Fig. 9. Expression of the $E$. coli lacl gene in Synechococcus. (a) RNA dot blot of the cells in Fig. 7 screened with a DNA probe specific for $E$. coli lac/9 mRNA. (b) Immunoblot of the cells in Fig. 7 screened with antiserum specific for the $E$. coli Lac repressor protein. The position of Lac repressor protein is marked with an asterisk. Lane $\mathrm{M}$ represents the positive control, E. coli PC2495 harbouring pTrc99C.

indicating that the precursor protein was recognized by the Synecbococcus protein-sorting machinery, and processed. In strain R2-MG77B cells, protein detected by the $\mathrm{PC}$ antiserum was observed only after induction with IPTG (lanes 3 and 4). In Synechococcus cells containing p'TrcIS, no PC could be detected (lanes 5 and 6). Fig. 8(b) shows the gel stained for total protein with Coomassie Brilliant Blue, displaying similar patterns in all lanes. In strain R2-MG77B cells, the trc promoter was efficiently shut off by the Lac repressor in the absence of IPTG. This was probably due to the efficient synthesis of the $38 \mathrm{kDa}$ lacI gene product in Synechococcus, which was similar to that in E. coli (Fig. 9).

The general usability of pTrcIS as a cloning vector for inducible, heterologous gene expression in Synechococcus PCC 7942 was confirmed by the introduction of the genes encoding Arabidopsis thaliana and Silene pratensis PC, Bacillus licheniformis $\alpha$-amylase, Streptococcus mutans fructosyltransferase and two Anabaena PC-Bacillus $\alpha$ amylase fusion proteins. For all genes studied, the desired recombinant clones were procured efficiently, and highlevel gene expression was found after induction with IPTG (results not shown). The transformants obtained were all stable for at least one year of continuous culturing without antibiotic selection.

\section{DISCUSSION}

Synechococcus R2-PIM9 was highly transformable by p'Trc99C-derived pMGx-A plasmids, but many transformants arose through illegitimate means. van der Plas et al. (1990) found that the percentage of transformants with the desired phenotype depended on the gene transferred and could be well below $100 \%$. The inability to select for 
the presence of the inserted gene diminished the general utility of the PIM. Consequently, the aad $A$ gene encoding $\mathrm{Sm}^{\mathrm{R}}$ as a second antibiotic-resistance marker was cloned into pTrc99C to force recombination in sequences flanking the inserted gene, resulting in vector pTrcIS. p TrcIK, containing the neo gene encoding $\mathrm{Km}^{\mathbf{R}}$, for use in Synechococcus R2-PIM8 $\left(\mathrm{Ap}^{\mathrm{S}} \mathrm{Sm}^{\mathrm{R}}\right.$ ) (van der Plas et al., 1990) was also constructed.

Using pTrcIS-derived $\mathrm{pMGx}$-B plasmids we were able to correctly introduce petE, uid $A$ and several other genes into the platform at high efficiency. The number of transformants with the desired phenotype using a pMGx$B$ plasmid is actually higher when the first screen is for an $\mathrm{Sm}^{\mathbf{R}}$ phenotype instead of for an $\mathrm{Ap}^{\mathbf{R}} \mathrm{Sm}^{\mathbf{R}}$ phenotype (Table 3), implying that screening for an $A p^{R}$ phenotype results in the loss of transformants with the proper phenotype. Synechococcus R2-MGx-A or -B clones containing the same insert gene showed similar expression patterns.

Maximum induction of the $\operatorname{trc} / \mathrm{lacI}$ system found with $E$. coli uid $A$ as a reporter gene was 36 -fold. With other genes tested, e.g. the Anabaena petE gene, the induction factor was even higher: densitometric scanning of protein blots of Synechococcus R2-MG77B showed about 100-fold induction (Geerts et al., 1994). The induced GUS activity could reach the level of constitutive GUS activity (in cells without a functional lacI gene), showing that derepression by inactivation of the Lac repressor was virtually total. The $E$. coli $\operatorname{trc}$ promoter in the uid $A$ gene fusion in Synecbococcus was almost fourfold stronger than the Anabaena PCC 7937 petF promoter [ 400 vs $120 \mathrm{nmol}$ MU $\min ^{-1}$ (mg protein $\left.)^{-1}\right]$, the strongest cyanobacterial promoter tested in Synechococcus PCC 7942 by Bovy et al. (1993).

The level of activity of the $E$. coli uid $A$ gene in R2MG139A and the Anabaena petE gene in R2-MG77B was very low in the absence of IPTG, meaning that there was saturating binding of the Lac repressor to the lac operator sequence. In a recently described plasmid-borne tac promoter/lacI repressor system used in Anabaena sp. PCC 7120 , repression by LacI resulted in only about fivefold repression (Elhai, 1993). The successful repression in our system could be due to the efficient synthesis of the Lac repressor (Fig. 9). The high-level expression of the lacI gene in Synechococcus in our system was surprising, since it is transcribed from its own promoter. The gene also contains 19 codons that are rarely used in Synechococcus (J. van der Plas and others, TNO, Zeist, The Netherlands, unpublished results), and it has been suggested that the use of rare codons reduces lacI expression in heterologous hosts, as in Zymomonas mobilis (Arfman et al., 1992).

Two different sizes of petE mRNA were found in Synecbococcus R2-MG77B and R2-MG95B, one of the correct length of approximately 740 bases, and a larger one of about 1030 bases (Fig. 7a). These bands are most likely the result of transcription termination at either of two strong stem-loop structures located downstream of the pet $\mathrm{E}$ gene: one ( $80 \mathrm{bp}$ downstream of the pet $\mathrm{E}$ gene, $\Delta G-18.2 \mathrm{kCal} \mathrm{mol}^{-1} ;-76 \mathrm{~kJ} \mathrm{~mol}^{-1}$ ) in the pet $E$ gene itself, the second one (446 bp downstream of the petE gene, $\Delta G-36.0 \mathrm{kCal} \mathrm{mol}^{-1} ;-151 \mathrm{~kJ} \mathrm{~mol}^{-1}$ ) in the $E$. coli $r r n B$ transcription terminator sequence in the vector. The pet $E$ mRNA is translated efficiently, resulting in accumulation of PC to a level similar to that found in Anabaena cells (Fig. 8a). Synechococcus cells expressing the Anabaena petE gene had a drastically enhanced photosynthetic activity, proving that the expressed PC was efficiently targeted to the thylakoid lumen, and properly folded with a functional copper centre (Geerts et al., 1994).

In contrast to other inducible gene expression systems described for cyanobacteria (Friedberg \& Seijffers, 1986; Marraccini et al., 1993; Mermet-Bouvier \& Chauvat, 1994), the expression system described in this paper did not seem to have pleiotropic effects on the cellular metabolism upon induction. Addition of IPTG at concentrations of up to $4 \mathrm{mM}$ did not result in any gross effect on the cell, as judged by Coomassie Brilliant Blue staining of total protein content (Fig. 8b), expression of the endogenous pet $F$ gene (Fig. $7 \mathrm{~b}$ ), growth rate (data not shown) or photosynthetic activity (Geerts et al., 1994).

\section{ACKNOWLEDGEMENTS}

The authors wish to thank Dr Egon Amann (Behringwerke AG, Marburg) for pTrc97C and pTrc99C, Dr Ponzy Lu (Department of Chemistry, University of Pennsylvania, PA, USA) for the lacI antiserum, Miss Annemieke Stoel for her involvement in DNA cloning and mutagenesis experiments and J. Dekker for help in the construction of p'TrcIS and initial analysis of recombinant Synecbococcus clones. We are indebted to Dr Jan van der Plas (TNO, Zeist, The Netherlands) for the 87-95/96 adaptor and stimulating discussions, and to Dr Michel Ebskamp for invaluable help in operating software and computers. This work was supported by the Foundation for Life Sciences (SLW, formerly BION) with financial aid (to D. G.) of the Netherlands Organization for Scientific Research (NWO).

\section{REFERENCES}

Amann, E., Ochs, B. \& Abel, K.-J. (1988). Tightly regulated tac promoter vectors useful for the expression of unfused and fused proteins in Eschericbia coli. Gene 69, 301-315.

Arfman, N., Worrell, V. \& Ingram, L. O. (1992). Use of the tac promoter and $\operatorname{lacl}^{\mathrm{q}}$ for the controlled expression of Zymomonas mobilis fermentation genes in Escherichia coli and Zymomonas mobilis. $J$ Bacteriol 174, 7370-7378.

Berry, J. \& Bjorkman, O. (1980). Photosynthetic response and adaptation to temperature in higher plants. Annu Rev Plant Physiol 31, 491-543.

Borbély, G., Surányi, G., Korcz, A. \& Pálfi, Z. (1985). Effect of heat shock on protein synthesis in the cyanobacterium Synechococcus sp. strain PCC 6301. J Bacteriol 161, 1125-1130.

Bovy, A., de Vrieze, G., Borrias, M. \& Weisbeek, P. (1992). Transcriptional regulation of the plastocyanin and cytochrome $c_{553}$ genes from the cyanobacterium Anabaena species PCC 7937. Mol Microbiol 6, 1507-1513.

Bovy, A., de Vrieze, G., Lugones, L., van Horssen, P., van den Bert, C., Borrias, M. \& Weisbeek, P. (1993). Iron-dependent stability of the ferredoxin I transcripts from the cyanobacterial strains Synechococcus PCC 7942 and Anabaena PCC 7937. Mol Microbiol 7, 429-439. 
Brosius, J. (1987). Expression vectors employing lambda-, trp-, lac-, and $l p p$-derived promoters. In Vectors: a Survey of Molecular Cloning Vectors and Their Use, pp. 205-225. Edited by R. J. Rodriguez \& D. T. Denhardt. Boston: Butterworths.

Bryant, D. A. (1992). Molecular biology of photosystem I. In Topics in Photosynthesis, vol. 11, The Photosystems: Structure, Function and Molecular Biology, pp. 501-549. Edited by J. Barber. Amsterdam: Elsevier.

Cai, Y. \& Wolk, C. P. (1990). Use of a conditionally lethal gene in Anabaena sp. strain PCC 7120 to select for double recombinants and to entrap insertion sequences. J Bacteriol 172, 3138-3145.

Carter, P., Bedouelle, H. \& Winter, G. (1985). Improved oligonucleotide site-directed mutagenesis using M13 vectors. Nucleic Acids Res 13, 4431-4443.

Dente, L. \& Cortese, R. (1987). pEMBL: a new family of singlestranded plasmids for sequencing DNA. Methods Enzymol 155, 111-118.

Elhai, J. (1993). Strong and regulated promoters in the cyanobacterium Anabaena PCC 7120. FEMS Microbiol Lett 114, 179-184.

Feinberg, A. P. \& Vogelstein, B. (1983). A technique for radiolabeling DNA restriction endonuclease fragments to high specificity. Anal Biocbem 132, 6-13.

Ferino, F. \& Chauvat, F. (1989). A promoter-probe vector-host system for the cyanobacterium, Synechocystis PCC6803. Gene 84, $257-266$.

Friedberg, D. \& Seijffers, J. (1986). Controlled gene expression utilising lambda phage regulatory signals in a cyanobacterial host. Mol \& Gen Genet 203, 505-510.

Geerts, D., Schubert, H., de Vrieze, G., Borrias, M., Matthijs, H. C. P. \& Weisbeek, P. J. (1994). Expression of Anabaena PCC 7937 plastocyanin in Synechococcus PCC 7942 enhances photosynthetic electron transfer and alters the electron distribution between PS I and cytochrome $c$ oxidase. $J$ Biol Chem 269, 28068-28075.

Gray, M. W. (1989). The evolutionary origins of organelles. Trends Genet 5, 294-299.

Houmard, J. \& Tandeau de Marsac, N. (1988). Cyanobacterial genetic tools: current status. Methods Enzymol 167, 808-847.

Jefferson, R. A., Burgess, S. M. \& Hirsh, D. (1986). $\beta$-Glucuronidase from Escherichia coli as a gene-fusion marker. Proc Natl Acad Sci US $A$ 83, 8447-8451.

Kuritz, T., Ernst, A., Black, T. \& Wolk, C. P. (1993). High-resolution mapping of genetic loci of Anabaena PCC 7120 required for photosynthesis and nitrogen fixation. Mol Microbiol 8, 101-110.

Labes, M., Puhler, A. \& Simon, R. (1990). A new family of RSF1010-derived expression and lac-fusion broad-host-range vectors for Gram-negative bacteria. Gene 89, 37-46.

Laemmli, U. K. (1970). Cleavage of structural proteins during the assembly of the head of bacteriophage T4. Nature 227, 680-685.

Marraccini, P., Bulteau, S., Cassier-Chauvat, C., Mermet-Bouvier, P. \& Chauvat, F. (1993). A conjugative plasmid vector for promoter analysis in several cyanobacteria of the genera Synechococcus and Synechocystis. Plant Mol Biol 23, 905-909.

Mermet-Bouvier, P. \& Chauvat, F. (1994). A conditional expression vector for the cyanobacteria Synechocystis sp. strains PCC 6803 and PCC 6714 and Synechococcus sp. strains PCC 7942 and PCC 6301. Curr Microbiol 28, 145-148.

Pilon, M., de Boer, A. D., Knols, S. L., Koppelman, M. H. G. M., van der Graaff, R. M., de Kruijff, B. \& Weisbeek, P. J. (1990). Expression in E. coli and purification of a translocation-competent precursor of the chloroplast protein ferredoxin. J Biol Chem 265, 3358-3361. van der Plas, J., Bovy, A., Kruyt, F., de Vrieze, G., Dassne, E., Klein, B. \& Weisbeek, P. (1989). The gene for the precursor of plastocyanin from the cyanobacterium Anabaena sp. PCC7937: isolation, sequence and regulation. Mol Microbiol 3, 275-284.

van der Plas, J., Hegeman, H., de Vrieze, G., Tyul, M., Borrias, M. \& Weisbeek, P. (1990). Genomic integration system based on pBR322 sequences for the cyanobacterium Synechococcus sp. PCC7942: transfer of genes encoding plastocyanin and ferredoxin. Gene 95, 39-48.

Porter, R. D. (1986). Transformation in cyanobacteria. Crit Rev Microbiol 13, 111-132.

Prentki, P., Binda, A. \& Epstein, A. (1991). Plasmid vectors for selecting IS1-promoted deletions in cloned DNA : sequence analysis of the omega interposon. Gene 103, 17-23.

Rippka, R., Deruelles, J., Waterbury, J. B., Herdman, M. \& Stanier, R. Y. (1979). Generic assignments, strain histories and properties of pure cultures of cyanobacteria. J Gen Microbiol 111, 1-61.

Rose, R. E. (1988). The nucleotide sequence of PACYC184. Nucleic Acids Res 16, 355.

Sambrook, J., Fritsch, E. F. \& Maniatis, T. (1989). Molecular Cloning: a Laboratory Manual, 2nd edn. Cold Spring Harbor, NY: Cold Spring Harbor Laboratory.

Scanlan, D. J., Bloye, S. A., Mann, N. H., Hodgson, D. A. \& Carr, N. G. (1990). Construction of lac $Z$ promoter probe vectors for use in Synechococcus: application to the identification of $\mathrm{CO}_{2}$-regulated promoters. Gene 90, 43-49.

Sleat, D. E., Gallie, D. R., Jefferson, R. A., Bevan, M. W., Turner, P. C. \& Wilson, T. M. A. (1987). Characterization of the 5 '-leader sequence of tobacco mosaic virus RNA as a general enhancer of translation in vitro. Gene 60, 217-225.

Stanier, R. Y. \& Cohen-Bazire, G. (1977). Phototrophic prokaryotes: the cyanobacteria. Annu Rev Microbiol 31, 225-274.

Tandeau de Marsac, N. \& Houmard, J. (1993). Adaptation of cyanobacteria to environmental stimuli: new steps towards molecular mechanisms. FEMS Microbiol Rev 104, 119-190.

Thiel, T. \& Poo, H. (1989). Transformation of a filamentous cyanobacterium by electroporation. J Bacteriol 171, 5743-5746.

Vermaas, W. (1993). Molecular biology approaches to analyze photosystem II structure and function. Annu Rev Plant Pbysiol Plant Mol Biol 44, 457-481.

Vorst, O., van Dam, F., Oosterhoff-Teertstra, R., Smeekens, S. \& Weisbeek, P. (1990). Tissue-specific expression directed by an Arabidopsis thaliana pre-ferredoxin promoter in transgenic tobacco plants. Plant Mol Biol 14, 491-499.

Wada, H. \& Murata, N. (1990). Temperature-induced changes in the fatty acid composition of the cyanobacterium, Synecbocystis PCC 6803. Plant Physiol 92, 1062-1069.

Williams, J. G. K. \& Szalay, A. A. (1983). Stable integration of foreign DNA into the chromosome of the cyanobacterium Synecbococcus R2. Gene 24, 37-51.

Wolk, C. P., Vonshak, A., Kehoe, P. \& Elhai, J. (1984). Construction of shuttle vectors capable of conjugative transfer from Escherichia coli to nitrogen-fixing filamentous cyanobacteria. Proc Natl Acad Sci US A 81, 1561-1565.

Yansura, D. G. \& Henner, D. J. (1984). Use of the Escherichia coli lac repressor and operator to control gene expression in Bacillus subtilis. Proc Natl Acad Sci US A 81, 439-443.

Received 15 September 1994; revised 4 December 1994; accepted 14 December 1994. 